\title{
Factors Affecting Taxpayer Compliance in Paying Natural and Building Taxes (Study in Datar Lebar II Village, Lungkang Kule District, Kaur Regency)
}

\section{Faktor-Faktor yang Mempengaruhi Kepatuhan Wajib Pajak dalam Membayar Pajak Bumi dan Bangunan (Studi di Desa Datar Lebar II Kecamatan Lungkang Kule Kabupaten Kaur)}

\author{
Elen Novita Maharani ${ }^{1}$; Ida Anggriani2); Herlin²) \\ 1)Study Program of Accountancy, Faculty of Economic, Universitas Dehasen Bengkulu \\ 2) Department of Accountancy, Faculty of Economic, Universitas Dehasen Bengkulu

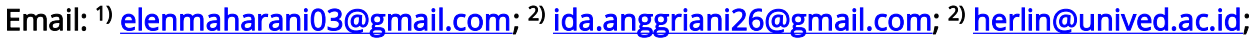

How to Cite:

Maharani, E. N., Anggriani, I., Herlin. (2021). Factors Affecting Taxpayer Compliance in Paying Natural and Building Taxes (Study in Datar Lebar II Village, Lungkang Kule District, Kaur Regency). EMAK: Jurnal Ekonomi Manajemen Akuntansi Dan Keuangan, 2(4). DOI: https://doi.org/10.53697/emak.v2i4

ARTICLE HISTORY

Received [12 Agust 2021]

Revised [25 Agust 2021]

Accepted [05 October 2021]

\section{KEYWORDS}

Taxpayers, Land and Building

$\operatorname{Tax}$

This is an open access article under the CC-BY-SA license

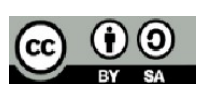

\section{ABSTRAK}

Tujuan penelitian ini adalah untuk mengetahui apakah pendapatan mempengaruhi kepatuhan wajib pajak dalam membayar pajak bumi dan bangunan (Studi di Desa Datar Lebar II Kecamatan Lungkang Kule Kabupaten Kaur). Untuk mengetahui apakah kesadaran mempengaruhi kepatuhan wajib pajak dalam membayar pajak bumi dan bangunan (Studi di Desa Datar Lebar II Kecamatan Lungkang Kule Kabupaten Kaur). c. Untuk mengetahui apakah kualitas pelayanan mempengaruhi kepatuhan wajib pajak dalam membayar pajak bumi dan bangunan (Studi di Desa Datar Lebar II Kecamatan Lungkang Kule Kabupaten Kaur). Berdasarkan hasil penelitian ini disimpulkan bahwa terdapat pengaruh pendapatan (X1) terhadap kepatuhan wajib pajak (Y) berdasarkan hasil uji tsig untuk variabel pendapatan (X1) adalah sebesar 0,021 nilai hitung tersebut tersebut jika di bandingkan dengan nilai a 0,05 dengan tingkat signifikan $0.021<5 \%$ untuk variabel pendapatan (X1) ini berarti Ha diterima dan Ho Ditolak yang artinya terdapat pengaruh pendapatan (X1) terhadap kepatuhan wajib pajak (Y). Terdapat pengaruh kesadaran (X2) terhadap kepatuhan wajib pajak (Y) berdasarkan hasil uji thitung untuk variabel kesadaran (X2) adalah sebesar 2,589 nilai thitung tersebut jika di bandingkan dengan ttabel sebesar 1.6991. karena thitung<ttabel $(2,589<1.6991)$ dengan tingkat segnifikan $0.023>5 \%$ maka $\mathrm{Ha}$ ditolak dan Ho diterima artinya pengaruh kesadaran (X2) terhadap kepatuhan wajib pajak (Y). Terdapat pengaruh kualitas layanan (X3) terhadap kualitas audit $(Y)$ berdasarkan hasil uji thitung untuk variabel kualitas layanan (X3) adalah sebesar 0,763 nilai thitung tersebut jika di bandingkan dengan ttabel sebesar 3.6991 karena thitung $<$ ttabel $(3.763<1.6991)$ dengan tingkat signifikan $0.042<5 \%$ maka Ha diterima dan Ho ditolak artinya pengaruh kualitas layanan (X3) terhadap kualitas audit (Y)..

\section{ABSTRACT}

The purpose of this study is to find out whether income affects taxpayer compliance in paying land and building taxes (Study in Datar Lebar II Village, Lungkang Kule District, Kaur Regency). To find out whether awareness affects taxpayer compliance in paying land and building taxes 
(Study in Datar Lebar II Village, Lungkang Kule District, Kaur Regency). c. This is to find out whether the quality of service affects taxpayer compliance in paying land and building taxes (Study in Datar Lebar II Village, Lungkang Kule District, Kaur Regency). Based on the results of this study it is concluded that there is an effect of income (X1) on taxpayer compliance $(Y)$ based on the results of the tsig test for variable income (X1) is 0.021 , the calculated value is compared with the a value of 0.05 with a significant level of $0.021<5 \%$ for the income variable (X1) means that Ha is accepted and Ho is rejected, which means that there is an effect of income (X1) on taxpayer compliance (Y). There is an effect of awareness (X2) on taxpayer compliance $(Y)$ based on the results of the t-test for the awareness variable (X2) which is 1.589 the value of the tcount when compared with the t-table of 1.6991. because tcount <ttable $(1.589<1.6991)$ with a significant level of $0.023>5 \%$, then $\mathrm{Ha}$ is rejected and Ho is accepted, which means the effect of awareness (X2) on taxpayer compliance $(Y)$. There is an effect of service quality $(X 3)$ on audit quality $(Y)$ based on the results of the $t$-test for the service quality variable (X3) which is 0.763 , the value of the $t$ count when compared with the t-table of 1.6991 because tcount <ttable $(0.763<1.6991)$ with a significant level of $0.042<5 \%$, then Ha is accepted and Ho is rejected, which means that the effect of service quality (X3) on audit quality $(Y)$..

\section{PENDAHULUAN}

Pajak merupakan salah satu sumber penerimaan negara yang sangat penting selain penerimaan lainnya yaitu penerimaan migas maupun penerimaan bukan pajak. Pemerintah berupaya secara terus menerus untuk meningkatkan target penerimaan negara dari sektor pajak. Pajak merupakan kontribusi wajib kepada negara yang terutang oleh orang pribadi atau badan yang bersifat memaksa berdasarkan Undang-Undang, dengan tidak mendapatkan imbalan secara langsung dan digunakan untuk keperluan daerah bagi sebesar-besarnya kemakmuran rakyat (UU No. 28 Tahun 2009).

Pemerintah Indonesia dalam melaksanakan kegiatan pembangunan tentunya memerlukan dana. Dana yang diperlukan untuk pembiayaan pembangunan salah satunya bersumber dari pungutan berupa pajak karena pajak diyakini sebagai tulang punggung pembangunan. Untuk itu, dalam rangka ikut menunjang pembiayaan dibutuhkan peran serta aktif dari masyarakat sebagai wajib pajak (WP) untuk ikut memberikan iuran kepada negara dalam bentuk pajak, sehingga segala aktivitas pembangunan dapat berjalan lancar. Adapun salah satu jenis pajak yang wajib dibayar oleh masyarakat sebagai wajib pajak adalah Pajak Bumi dan Bangunan (PBB).

Kepatuhan yang tinggi dari wajib pajak dibutuhkan untuk kelancaran penarikan pajak. Begitu pula dalam pemungutan Pajak Bumi dan Bangunan juga dibutuhkan kepatuhan yang tinggi dari WP PBB. Kepatuhan wajib pajak adalah suatu keadaan dimana wajib pajak memenuhi semua kewajiban perpajakan dan melaksanakan hak perpajakannya. Namun dalam kenyataannya negara sering kesulitan memungut pajak yang salah satunya adalah Pajak Bumi dan Bangunan (PBB). Kendala di dalam menerapkan optimalisasi perpajakan adalah masih rendahnya tingkat kepatuhan wajib pajak dan kepercayaan masyarakat kepada administrasi pengelola pajak. Pemerintah daerah dalam pelaksanaan penarikan PBB masih banyak menghadapi kendala antara lain masih kurangnya kesadaran masyarakat dalam membayar PBB (Agung dan Adi, 2013:2).

Salah satu hal yang mempengaruhi wajib pajak dalam melaksanakan kewajibannya sebagai warga Negara yang baik adalah kepatuhan dalam membayar pajak.Semakin tinggi kepatuhan wajib pajak, maka penerimaan pajak akan semakin meningkat,demikian pula sebaliknya (Lestari, 2017:12) Kepatuhan wajib pajak yaitu dimanawajib pajak memenuhi kewajiban perpajakannya dan melaksanakan hak perpajakan dengan baik dan benar sesuai dengan peraturan dan undangundang pajak yang berlaku. Salah satu upaya dalam meningkatkan kepatuhan wajib pajak yaitu 
memberikan pelayanan yang baik kepada wajib pajak. Adapun prasangka sebagian besar masyarakat terhadap petugas pajak harus dirubah menjadi prasangka baik,untuk merubah hal tersebut tentu harus menciptakan dan meningkatkan pelayanan yang berkualitas. Dengan peningkatan kualitas pelayanan yang baik diharapkan dapat meningkatkan kepatuhan dalam bidang perpajakan. Karena Masyarakat akan membayar pajak apabila mereka merasakan pelayanan publik sebanding dengan pembayaran pajaknya.

Oladipupo dan Obazee (2016:54) menyatakan bahwa faktor-faktor yang memengaruhi rendahnya tingkat kepatuhan pajak di negara-negara berkembang antara lain sikap, hukuman/sanksi, pendapatan, pengetahuan, jenis kelamin dan usia wajib pajak, korupsi, tingkat pajak marjinal yang tinggi, kurangnya ketersediaan sistem informasi dan akuntansi, sektor informal yang besar, sistem peraturan yang lemah, ambiguitas dalam undang- undang perpajakan, adanya budaya yang tidak patuh, dan ketidakefektifan administrasi perpajakan.

Menurut James dan Alley (2014:112) menyatakan bahwa tidak mudah membujuk semua wajib pajak untuk mematuhi semua persyaratan sistem perpajakan. Kepatuhan pajak cenderung menjadi aspek yang lebih signifikan dari kebijakan pajak. Hal ini disebabkan sebagian besar masalah lama yang masih tetap ada dan adanya pertimbangan baru yang berkembang seperti self assessment, kemunculan ekonomi global, dan perdagangan elektronik.

\section{LANDASAN TEORI}

\section{Kepatuhan wajib pajak}

Adalah kepatuhan dan kesadaran pemenuhan kewajiban perpajakan, tercermin dalam situasi dimana wajib pajak paham atau berusaha untuk memahami semua ketentuan peraturan perundang- undangan perpajakan, mengisi formulir pajak dengan lengkap dan jelas, menghitung jumlah pajak yang terutang dengan benar, membayar pajak yang terutang tepat pada waktunya pada masyarakat di Desa Datar Lebar II Kecamatan Lungkang Kule Kabupaten Kaur. Dengan indikator yaitu kelancaran, ketepatan waktu dan ketaatan

\section{Pendapatan}

Menurut adalah tanggungan jumlah uang atau nilai yang selama tahun takwim diperoleh masyarakat di Desa Datar Lebar II Kecamatan Lungkang Kule Kabupaten Kaur dengan indikator terdiri dari pendapatan dari pekerjaan, penghasilan dari modal, pendapatan dari kegiatan usaha

\section{Kesadaran}

Adalah semakin rakyat maju dan pemerintahannya juga maju, rakyat akan semakin tinggi kesadaran pajaknya namun di pihak lain rakyat akan semakin kritis, tapi bukan mengritisi keberadaan pajak itu sendiri sebagai sebuah instrumen, seperti sebelumnya, melainkan kritis terhadap materi kebijakan di bidang perpajakannya, yakni tarif, dan perluasan pada masyarakat di Desa Datar Lebar II Kecamatan Lungkang Kule Kabupaten Kaur. Adapun Indikator kesadaran perpajakan ditunjukandengan: Mengetahui fungsi pajak dan Kesadaran membayar pajak

\section{Pelayanan}

Adalah suatu proses bantuan kepada orang lain dengan cara- cara tertentu yang memerlukan kepekaan dan hubungan interpersonal agar terciptanya kepuasan dan keberhasilan pada masyarakat di Desa Datar Lebar II Kecamatan Lungkang Kule Kabupaten Kaur dengan indikator terdiri dari sederhana, terbuka, lancar, tepat, lengkap, wajar dan terjangkau 
p-ISSN 2798-0499 e-ISSN 2798-0502

\section{METODE PENELITIAN}

\section{Metode Analisis}

Pada penelitian ini data yang digunakan adalah data kuantitatif, yaitu data yang diperoleh dari menyebarkan kuesioner kepada wajib pajak Bumi dan Bangunan di Desa Datar Lebar II. Pada penelitian ini peneliti melakukan perhitungan dengan menggunakan komputer program statistik seperti program SPSS versi 17. Untuk membahas masalah penelitian dengan menggunakan alat analisis statistik sebagai berikut :

1. Uji Validitas

Menurut Sugiyono (2013:334) validitas adalah alat untuk mengukur sah atau tidaknya kuesioner. Kuesioner dikatakan valid jika pertanyaan kuesioner mampu untuk menggungkapkan sesuatu yang telah di ukur oleh kuesioner tersebut. Penghitungan menggunakan komputer dengan aplikasi SPSS 17, untuk menentukan signifikan atau tidak signifikan dengan membandingkan hitung dengan tabel untuk $\mathrm{df}=\mathrm{n}-\mathrm{k}$ dan $a=5 \%$ dengan perhitungan :

a. Jika rhitung $\geq$ dari rtabel maka butir pertanyaan dikatakan valid.

b. Jika rhitung $\leq$ dari rtabel maka butir pertanyaan dikatakan tidak valid.

2. Uji Reliabilitas

Menurut Sugiyono (2013:123) reliabilitas adalah alat ukur untuk mengukur suatu kuesioner merupakan indikator dari variabel atau konstruk. Butir pertanyaan merupakan reliable atau handal apabila jawaban seseorang terhadap pertanyaan adalah konsisten. Perhitungan menggunakan komputer dengan aplikasi SPSS 17 dan Fasilitas Cronbach alpha (a). Jika konstruk dikatakan reliable jika memberikan nilai Cronbacha > dari 0,60.

3. Uji Normalitas

Pembuktian data tersebut memiliki distribusi normal atau tidak dapat dilihat pada bentuk distribusi datanya. Uji normalitas data dilakukan untuk menentukan data yang telah dikumpulkan berdistribusi normal atau diambil dari populasi normal, Sugiyono (2013:335). Untuk mengujinya digunakan Kolmomogorov-Smirnov. Untuk menentukan normalitas digunakan pedoman sebagai berikut:

a. Signifikansi uji $(\alpha)=0,05$

b. Jika Sig > a, maka sampel beracal dari populasi yang berdistribusi normal.

c. Jika Sig < a, maka sampel bul rasal dari populasi yang berdistribusi normal.

4. Analisis Regresi Berganda

Model regresi linier sederhana digunakan untuk menganalisis pengaruh dari variabel $X$ terhadap satu variabel $Y$ Sugiyono (2013:339).

$$
Y=\beta_{0}+\beta_{1} X_{1}+\beta_{2} X_{2}+\beta_{3} X_{3}+\text { ei }
$$

Keterangan:

$\mathrm{Y}=$ Kepatuhan membayar pajak

$\beta_{0}=$ Konstanta

$\beta_{1} \beta_{2}=$ Koefisien regresi (pendapatan, kesadaran dan kualitas pelayanan )

ei $=$ Variabel Pengganggu

5. Uji T (Parsial)

Menurut Imam Ghoze $\quad$ Im (2011:180) uji parsial dilakukan untuk menentukan signifikan atau tidak masing-masing nilai koefisien regresi $(b 1, b 2, b 3)$ secara sendiri-sendiri terhadap variabel terikat ( $\mathrm{Y}$ ). Pengujian secara parsial menggunakan distribusi $t$ yaitu membandingkan thitung dengan tabel. Langkah pengujian secara parsial dengang cara menentukan Ho dan Ha, yakni : 
a. Ho: b1 $=0$ berarti nilai koefisien prediktor variabel independen tidak berpengaruh signifikan terhadap variabel independen.

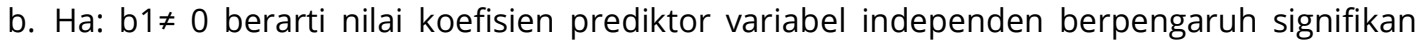
terhadap variabel independen.

Rumus uji parsial sebagai berikut:

$t b n=\frac{b n}{s b n}$

Keterangan :

$\mathrm{T} \quad=$ nilai t hitung

$\mathrm{bn} \quad=$ konstanta regresi

$\mathrm{Sb}=$ kesalahan buku penduga (Ghozali, Imam, 2011:141)

Cara pengujian dengan membandingkan thitung dengan ttabel, apabila :

6. Uji F (Simultan)

a. Ho diterima jika $t_{\text {sig }} \geq a(0,05)$

b. Ha ditolak jika $t_{\text {sig }}<a(0,05)$

Menurut Ferdinand (2014:178) uji simultan ini melibatkan semua variabel bebas (kecerdasan emosional, kecerdasan spiritual dan perilaku etis) terhadap variabel terikat (kualitas audit) dalam menguji ada tidaknya pengaruh yang signifikan secara simultan. Pengujian secara simultan menggunakan distribusi $f$ yaitu membandingkan $f_{\text {hitung }}$ dengan $f_{\text {tabel. }}$ Langkah pengujian secara $s$ an dengan cara menentukan Ho dan Ha, yakni :

a. Ho:b1,b2,b3 = 0 berarti nilà nuefisien regresi prediktor pendapatan, kesadaran dan kualitas pelayanan tidak berpengaruh signifikan terhadap kepatuhan wajib pajak.

b. Ha:b1,b2,b3 $\neq 0$ berarti nilai koefisien regresi prediktor pendapatan, kesadaran dan kualitas pelayanan berpengaruh signifikan terhadap kepatuhan wajib pajak.

Rumus uji f sebagai berikut:

F hitung $=\frac{\mathrm{R}^{2}(\mathrm{~N}-\mathrm{m}-1)}{\mathrm{m}\left[1-\mathrm{R}^{2}\right)}$

Keterangan

$\mathrm{F}=$ Nilai $\mathrm{F}$ Hitung

$R^{2}=$ Koefisien determinasi berganda

$N=$ Jumlah sampel

$m=$ Jumlah variabel

Cara pengujian dengan membandingkan $F_{\text {hitung }}$ dengan $F_{\text {tabel, }}$ apabila:

a. Ho diterima jika $f_{\text {hitung }}<f_{\text {tabel }}$ artinya secara simulan variabel $X$ tidak berpengaruh terhadap variabel $\mathrm{Y}$.

b. Ha ditolak jika $f_{\text {hitung }}>f_{\text {tabel }}$ artinya secara simultan variabel mempunyai pengaruh terhadap variabel $Y$.

7. Koefisien Determinasi r (Korelasi)

Koefisien determinasi adalah uji yang digunakan dalam untuk mengetahui kekuatan hubungan (Sugiyono, 3:339). Untuk mengetahui seberapa besar pengaruh antar variabel digunakan interpretasi sebagai berikut:

$$
\mathrm{R}^{2}=r \times 100
$$

Tabel 1. Kriteria Interval Kekuatan Hubungan Koefisien Determinasi

\begin{tabular}{|c|c|c|}
\hline No. & Nilai Interval & Kekuatan hubungan \\
\hline 1 & $0,00-0,199$ & Sangat Rendah \\
\hline 2 & $0,20-0,399$ & Rendah \\
\hline 3 & $0,40-0,599$ & Sedang \\
\hline 4 & $0,60-0,799$ & Kuat \\
\hline 5 & $0,80-1,000$ & Sangat Kuat \\
\hline
\end{tabular}

Sumber: Sugiyono (2013:203) 


\section{HASIL DAN PEMBAHASAN}

\section{Hasil dan Pembahasan}

Analisis Regresi Berganda

Uji regresi ini untuk menganalisis besarnya pengaruh dan variabel independen (Pendapatan, Kesadaran, Kualitas layanan) terhadap variabel dependen (Kepatuhan wajib pajak auditior). Perhitungan ini menggunakan aplikasi SPSS 17 yang terlihat tabel di bawah ini :

Tabel 2. Hasil Output SPSS Pengujian Regresi Linear Berganda

\section{Coefficients $^{a}$}

\begin{tabular}{|c|c|c|c|c|c|}
\hline \multirow{2}{*}{ Model } & \multicolumn{2}{|c|}{ Unstandardized Coefficients } & \multirow{2}{*}{$\begin{array}{c}\text { Standardized Coefficients } \\
\text { Beta }\end{array}$} & \multirow{2}{*}{$\mathrm{t}$} & \multirow{2}{*}{ Sig. } \\
\hline & B & Std. Error & & & \\
\hline (Constant) & 31.901 & 8.768 & & 3.639 & .001 \\
\hline $\mathrm{X} 1$ & .579 & .236 & .561 & 2.455 & .021 \\
\hline $\mathrm{X} 2$ & .296 & .186 & 267 & 2.589 & .023 \\
\hline X3 & .153 & .200 & .172 & 3.763 & .042 \\
\hline
\end{tabular}

a. Dependent Variable: $Y$

Sumber: Hasil Penelitian, data diolah 2021

Berdasarkan data diatas dapat dilihat persamaan regresi berganda pada variabel pendapatan, kesadaran dan kualitas pelayanan (variabel independen) terhadap kepatuhan wajib pajak (independen) persamaan regresi sebagai berikut:

$Y=a+b_{1}\left(X_{1}\right)+b_{2}\left(X_{2}\right)+b_{3}\left(X_{3}\right)$

$Y=31,901+0,579\left(X_{1}\right)+0,296\left(X_{2}\right)+0,153\left(X_{3}\right)$

Sedangkan untuk koefesien regresi dari masing-masing variabel dapat di jelaskan sebagai berikut :

1. Nilai konstanta sebesar 31,901 mempunyai arti bahwa apabila pendapatan $\left(X_{1}\right)$, kesadaran $\left(X_{2}\right)$ dan kualitas layanan sama dengan nol maka kepatuhan wajib pajak di desa Datar Lebar II akan konstan sebesar 31,901 hal ini berlaku saat di lakukan penelitian

2. $\beta 1=0,579$

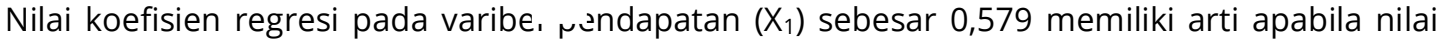
variabel pendapatan berubah sebanyak satu satuan maka akan diikuti dengan perubahan variabel kepatuhan wajib pajak (Y) sebesar 0,579 di Desa Datar Lebar II dengan asumsi menggangap variabel lain adalah tetap.

3. $\beta 2=0,296$

Nilai koefisien regresi pada variabel kesadaran $\left(X_{2}\right)$ sebesar 0,296 memiliki arti apabila variabel kesadaran $\left(\mathrm{X}_{2}\right)$ berubah sebanyak satu satuan maka akan diikuti dengan perubahan variabel kepatuhan wajib pajak (Y) sebesar 0,296 di Desa Datar Lebar II dengan asumsi menganggap variabel lain adalah tetap.

4. $\beta 3=0,153$

Nilai koefisien regresi pada varibel kualitas layanan (X3) sebesar 0,153 memiliki arti apabila nilai variabel kualitas pelayanan berubah sebanyak satu satuan maka akan diikuti dengan perubahan variabel kepatuhan wajib pajak (Y) sebesar 0,153 di Desa Datar Lebar II dengan asumsi menggangap variabel lain adalah tetap.

Uji T Parsial

Uji t ini berfungsi untuk menguji hipotesis yang bersifat terpisah dengan $a=\operatorname{taraf}$ signifikan satu arah pada derajat 0.05. Uji t parsial di gunakan untuk menguji apakah terhadap pengaruh yang signifikan antara variabel bebas terhadap variabel terikat : 
Tabel 3. Hasil Output SPSS Uji Parsial

Coefficients $^{a}$

\begin{tabular}{|c|c|c|c|c|c|c|}
\hline \multirow{2}{*}{\multicolumn{2}{|c|}{ Model }} & \multicolumn{2}{|c|}{ Unstandardized Coefficients } & \multirow{2}{*}{$\begin{array}{c}\text { Standardized Coefficients } \\
\text { Beta }\end{array}$} & \multirow{2}{*}{$\mathrm{t}$} & \multirow{2}{*}{ Sig. } \\
\hline & & B & Std. Error & & & \\
\hline 1 & (Constant) & 31.901 & 8.768 & & 3.639 & .001 \\
\hline & $\mathrm{X} 1$ & .579 & .236 & .561 & 2.455 & .021 \\
\hline & $\times 2$ & .296 & .186 & .267 & 2.589 & .023 \\
\hline & X3 & .153 & .200 & .172 & 3.763 & .042 \\
\hline
\end{tabular}

a.

Dependent

Variable: $Y$

Sumber: Hasil Penelitian, data diolah 2021

Dari perhitungam dengan rumus program SPSS, diperoleh nilai thitung setiap variabel adalah :

1. Pengaruh pendapatan $\left(X_{1}\right)$ terhadap kepatuhan wajib pajak $(Y)$ berdasarkan hasil uji $t_{\text {sig }}$ untuk variabel pendapatan $\left(X_{1}\right)$ adalah sebesar 0,021 nilai hitung tersebut tersebut jika di bandingkan dengan nilai a 0,05 dengan tingkat signifikan $0.021<5 \%$ untuk variabel pendapatan (X1) ini berati Ha diterima dan Ho Ditolak.

2. Pengaruh Kesadaran $\left(X_{2}\right)$ terhadap kepatuhan wajib pajak $(Y)$ berdasarkan hasil uji $t_{\text {sig }}$ untuk variabel Kesadaran $\left(\mathrm{X}_{2}\right)$ adalah sebesar 0,023 nilai hitung tersebut tersebut jika di bandingkan dengan nilai a 0,05 dengan tingkat signifikan $0.023<5 \%$ untuk variabel pendapatan $\left(X_{2}\right)$ ini berati Ha diterima dan Ho Ditolak.

3. Pengaruh kualitas layanan $\left(X_{3}\right)$ terhadap kepatuhan wajib pajak $(Y)$ berdasarkan hasil uji $t_{\text {sig }}$ untuk variabel Kesadaran $\left(X_{3}\right)$ adalah sebesar 0,042 nilai hitung tersebut tersebut jika di bandingkan dengan nilai a 0,05 dengan tingkat signifikan $0.042<5 \%$ untuk variabel pendapatan $\left(\mathrm{X}_{3}\right)$ ini berati Ha diterima dan Ho Ditolak.

4.

Uji F Simultan

Uji simultan ini bertujuan untuk mengetahui apakah variabel pendapatan, kesadaran dan kualitas pelayanan secara bersama-sama dapat mempengaruhi kepatuhan wajib pajak.

Tabel 4. Hasil Output SPSS Uji F

Tabel 4. Hasil ANOVA

ANOVA $^{b}$

\begin{tabular}{|c|c|c|c|c|c|c|}
\hline \multicolumn{2}{|r|}{ Model } & Sum of Squares & df & Mean Square & $F$ & Sig. \\
\hline \multirow[t]{3}{*}{1} & Regression & 238.083 & 3 & 79.361 & 7.894 & $.043^{\mathrm{a}}$ \\
\hline & Residual & 767.917 & 28 & 27.426 & & \\
\hline & Total & 1006.000 & 31 & & & \\
\hline
\end{tabular}

Sumber: Hasil Penelitian, data diolah 2021

Dari hasil perhitungan dengan menggunakan SPSS terlihat pada tabel yang diperoleh besarnya $F_{\text {hitung }}$ adalah 7,894 sedangkan nilai $F_{\text {tabel }}$ digunakan taraf signifikan $5 \%$ dengan $\mathrm{df}=\mathrm{n} \mathrm{k}$ $1=32-3-1=28$, sehingga diperoleh hasil $F_{\text {tabel }}$ sebesar 2.95 karena $F_{\text {hitung }}>F_{\text {tabel }}(7,894>2.95)$ maka $\mathrm{H}_{a}$ diterima dan $\mathrm{H}_{\mathrm{o}}$ ditolak artinya berpengaruh signifikan dari variabel pendapatan $\left(\mathrm{X}_{1}\right)$, kesadaran $\left(\mathrm{X}_{2}\right)$ dan kualitas layanan $\left(\mathrm{X}_{3}\right)$ secara bersama-sama atau simultan terhadap kepatuhan wajib pajak $(\mathrm{Y})$. 
Uji Koefisien Determinasi ( R Square )

Berikut ini adalah hasil uji koefisien determinasi $\left(R^{2}\right)$, hasil uji $R^{2}$ digunakan untuk mengetahui seberapa besar persentase sumbangan pengaruh variabel independen secara serentak terhadap variabel dependen. Berikut tabel hasil uji $\mathrm{R}^{2}$ :

Tabel 5. Hasil Output SPSS Uji Koefisien Determinasi $\left(R^{2}\right)$

Model Summary ${ }^{b}$

\begin{tabular}{|l|r|r|r|r|r|}
\hline Model & R & R Square & Adjusted R Square & Std. Error of the Estimate & Durbin-Watson \\
\hline 1 & $.774^{\mathrm{a}}$ & .553 & .455 & 5.237 & 2.370 \\
\hline
\end{tabular}

a. Predictors: (Constant), X3, X2, X1

b. Dependent Variable: $Y$

Sumber: Hasil Penelitian, data diolah 2021

Nilai R berkisar antara 0 sampai 1, jika mendekati 1 maka hubungan semakin erat tetapi jika mendekati 0 maka hubungan semakin lemah. Dari tabel diatas nilai korelasi penelitian ini adalah $\mathrm{R}=$ 0,774 didapat nilai koefisien diterminasi Adjusted $R$ Square $R^{2}=0,553$. Nilai ini mempunyai arti bahwa variabel independen secara bersama-sama memberikan sumbangan sebesar $55,3 \%$ dalam mempengaruhi variabel dependen dengan kriteria sedang. Hal ini berarti terjadi hubungan yang sedang, sedangkan sisanya dipengaruhi oleh variabel-variabel lain yang tidak diteliti.

Pembahasan

Analisis menggunakan software SPSS, dimana hasil pengujian statistik ini dapat dilihat dalam tabel berikut:

Tabel 6. Hasil Pengujian Hipotesis

\begin{tabular}{|l|c|c|c|c|c|}
\hline \multicolumn{1}{|c|}{ Variabel } & Koefisien & Nilai Koefisien & $t_{\text {hitung }}$ & $t_{\text {sig }}$ & Hipotesis \\
\hline Konstanta & $a$ & 31.901 & & & \\
\hline Pendapatan & $b_{1}$ & 0,579 & 2,455 & 0,21 & Diterima \\
\hline Kesadaran & $b_{2}$ & 0,296 & 2,589 & 0,23 & Diterima \\
\hline Kualitas Pelayanan & $b_{3}$ & 0,153 & 3,763 & 0,42 & Diterima \\
\hline R Square & \multicolumn{5}{|c|}{$55,3 \%$} \\
\hline
\end{tabular}

1. Pengaruh pendapatan terhadap Kepatuhan wajib pajak dalam membayar pajak bumi dan bangunan di Desa Datar Lebar II Kecamatan Lungkang Kule Kabupaten Kaur.

Berdasarkan hasil penelitian yang telah dilakukan oleh peneliti bahwa terdapat pengaruh pendapatan $\left(\mathrm{X}_{1}\right)$ terhadap kepatuhan wajib pajak $(\mathrm{Y})$ berdasarkan hasil uji $\mathrm{t}_{\text {sig }}$ untuk variabel pendapatan $\left(X_{1}\right)$ adalah sebesar 0,021 nilai hitung tersebut tersebut jika di bandingkan dengan nilai a 0,05 dengan tingkat signifikan $0.021<5 \%$ untuk variabel pendapatan (X1) ini berati $\mathrm{Ha}$ diterima dan Ho Ditolak.

Permasalahan yang akan dihadapi auditor dalam dunia kerja ada berbagai jenis. Untuk menghadapi permasalahan tersebut tidak cukup dengan mengandalkan kecerdasan intelektual auditor saja tetapi juga diperlukan peranan pendapatan dalam mengatasi permasalahan tersebut. Menurut Goleman dalam Surya dan Hananto (2004) mengatakan bahwa koordinasi suasana hati adalah inti dari hubungan sosial yang baik. Apabila seseorang pandai menyesuaikan diri dengan suasana hati individu yang lain atau dapat berempati, orang tersebut akan memiliki tingkat emosionalitas yang baik dan akan lebih mudah menyesuaikan diri dalam pergaulan sosial serta lingkungannya. Menurut Goleman (2006:109) berpendapat bahwa pendapatan merupakan landasan dari kecakapan emosi, dimana kecakapan emosi ini merupakan penyebab terjadinya peningkatan kinerja. Kecerdasan ini akan mempertinggi potensi karyawan dalam belajar, 
sedangkan kecakapan emosi akan menjadikan potensi itu menjadi keahlian dalam menjalankan tugas.

Hal ini didukung oleh penelitian Muhammad Fadjar (2014) dimana 1) Terdapat pengaruh positif dan signifikan Pendapatan terhadap kepatuhan wajib pajak 2) Terdapat pengaruh positif dan signifikan Kesadaran terhadap kepatuhan wajib pajak 3) terdapat pengaruh positif dan signifikan Tekanan Klien terhadap kepatuhan wajib pajak

2. Pengaruh Kesadaran terhadap Kepatuhan wajib pajak dalam membayar pajak bumi dan bangunan di Desa Datar Lebar II Kecamatan Lungkang Kule Kabupaten Kaur

Berdasarkan hasil penelitian yang telah dilakukan oleh peneliti maka terdapat pengaruh kesadaran $\left(\mathrm{X}_{2}\right)$ terhadap kepatuhan wajib pajak $(\mathrm{Y})$ berdasarkan hasil uji thitung untuk variabel kesadaran $\left(X_{2}\right)$ adalah sebesar 1,589 nilai thitung tersebut jika di bandingkan dengan tabel sebesar 1.6991. karena $t_{\text {hitung }}<\mathrm{t}_{\text {tabel }}(1,589<1.6991)$ dengan tingkat signifikan $0.023>5 \%$ maka Ha ditolak dan Ho diterima.

Kesadaran merupakan perasaan terhubungkan dengan diri sendiri, orang lain dan alam semesta secara utuh pada saat orang bekerja, maka ia dituntut untuk mengarahkan intelektualnya, tetapi banyak hal yang membuat seseorang senang dengan pekerjaannya. Mereka yang dapat memberi makna pada hidup mereka dan membawa spiritualitas kedalam lingkungan kerja mereka akan membuat mereka menjadi orang yang lebih baik, sehingga kepatuhan wajib pajak yang dihasilkan juga lebih baik dibanding mereka yang bekerja tanpa memiliki kesadaran (Hoffman, 2002:133). Hal ini juga didukung oleh hasil Penelitian Imelda (2012) yang meneliti tentang pengaruh kesadaran terhadap kepatuhan wajib pajak menunjukkan hasil bahwa kesadaran berpengaruh terhadap kepatuhan wajib pajak. Hasil penelitian eleven dengan penelitian Apriyani (2014) Pendapatan, Kesadaran dan Kualitas layanan berpengaruh Terhadap Kepatuhan wajib pajak BPK-RI dan BPKP Perwakilan Provinsi Riau.

3. Pengaruh Kualitas pelayanan terhadap Kepatuhan wajib pajak dalam membayar pajak bumi dan bangunan di Desa Datar Lebar II Kecamatan Lungkang Kule Kabupaten Kaur.

Berdasarkan hasil penelitian bahwa terdapat pengaruh kualitas layanan $\left(X_{3}\right)$ terhadap kualitas audit $(\mathrm{Y})$ berdasarkan hasil uji thitung untuk variabel kualitas layanan $\left(\mathrm{X}_{3}\right)$ adalah sebesar 0,763 nilai thitung tersebut jika di bandingkan dengan $t_{\text {tabel }}$ sebesar 1.6991 karena $t_{\text {hitung }}<t_{\text {tabel }}$ $(0.763<1.6991)$ dengan tingkat signifikan $0.042<5 \%$ maka Ha diterima dan Ho ditolak.

Etika profesi khusus berlaku dalam kelompok profesi yang bersangkutan, yang mana dalam penelitian ini adalah auditor. Masyarakat akan menghargai profesi yang menerapkan standar mutu yang tinggi dalam pelaksanaan pekerjaannya. Auditor wajib menaati segala peraturan perundang-undangan yang berlaku, menyimpan rahasia jabatan, menjaga semangat dan suasana kerja yang baik. Kualitas layanan juga sering disebut sebagai komponen dari kepemimpinan, yang mana pengembangan etika adalah hal penting bagi kesuksesan individu sebagai pemimpin suatu organisasi (Morgan, dalam Nugrahaningsih, 2005). Adapun beberapa penelitian mengenai kualitas layanan auditor salah satunya dilakukan oleh Lilik Henry Ristanto (2009) dengan penelitiannya yang beriıdıl pengaruh pendapatan dan kualitas layanan terhadap kepatuhan wajib pajak pemerintah ah (studi empiris pada inspektorat jawa tengah) membuktikan bahwa pendapatan dan kualitas pelayanan pada auditor pemerintah daerah berpengaruh positif terhadap kepatuhan wajib pajak pemerintah. Dari uraian diatas dapat diketahui bahwa kualitas layanan tidak terlepas dari diri auditor. Apabila auditor dapat berkualitas layanan sesuai dengan kode etik profesinya, memahami kode etik profesinya maka akan berpegaruh dalam meningkatkan kepatuhan wajib pajak dari auditor tersebut. Auditor yang berkualitas layanan akan secara otomatis menunjukkan kepatuhan wajib pajak yang baik, karena kepatuhan wajib pajak dapat dinilai baik tidaknya dari tindakan auditor dalam melaksanakan tugasnya apakah sudah berkualitas layanan sesuai kode etik profesinya atau tidak.

Hal ini didukung oleh penelitian Muhammad Fadjar (2014) dimana 1) Terdapat pengaruh positif dan signifikan Pendapatan terhadap kepatuhan wajib pajak 2) Terdapat pengaruh positif 
dan signifikan Kesadaran terhadap kepatuhan wajib pajak 3) terdapat pengaruh positif dan signifikan Tekanan Klien terhadap kepatuhan wajib pajak.

\section{KESIMPULAN DAN SARAN}

\section{Kesimpulan}

1. Terdapat pengaruh pendapatan (X1) terhadap kepatuhan wajib pajak (Y) berdasarkan hasil uji thitung untuk variabel kualitas layanan (X1) adalah sebesar 2,455 nilai thitung tersebut jika di bandingkan dengan ttabel sebesar 1.6991 karena thitung<ttabel $(2,455<1.6991)$. Hasil uji tsig untuk variabel pendapatan (X1) adalah sebesar 0,021 nilai hitung tersebut jika di bandingkan dengan nilai a 0,05 dengan tingkat signifikan $0.021<5 \%$ untuk variabel pendapatan (X1) ini berarti Ha diterima dan Ho Ditolak. Artinya terdapat pengaruh pendapatan (X1) terhadap kepatuhan wajib pajak (Y).

2. Terdapat pengaruh kesadaran (X2) terhadap kepatuhan wajib pajak (Y) berdasarkan hasil uji thitung untuk variabel kesadaran (X2) adalah sebesar 2,589 nilai thitung tersebut jika di bandingkan dengan ttabel sebesar 1.6991. karena thitung<ttabel $(2,589<1.6991)$ dengan tingkat segnifikan $0.023>5 \%$ maka Ha ditolak dan Ho diterima artinya pengaruh kesadaran (X2) terhadap kepatuhan wajib pajak (Y).

3. Terdapat pengaruh kualitas layanan (X3) terhadap kualitas audit (Y) berdasarkan hasil uji thitung untuk variabel kualitas layanan (X3) adalah sebesar 3,763 nilai thitung tersebut jika di bandingkan dengan ttabel sebesar 1.6991 karena thitung<ttabel $(3.763<1.6991)$ dengan tingkat signifikan $0.042<5 \%$ maka Ha diterima dan Ho ditolak artinya pengaruh kualitas layanan (X3) terhadap kualitas audit $(Y)$.

4. Dari hasil perhitungan besarnya Fhitung adalah 7,894 sedangkan nilai Ftabel digunakan taraf signifikan 5\% dengan df=n $\mathrm{k}-1=32-3-1=28$, sehingga diperoleh hasil Ftabel sebesar 2.95 karena Fhitung>Ftabel $(7,894>2.95)$ maka Ha diterima dan Ho ditolak artinya berpengaruh signifikan dari variabel pendapatan (X1), kesadaran (X2) dan kualitas layanan (X3) secara bersama-sama atau simultan terhadap kepatuhan wajib pajak (Y).

5. Hasil Ftabel sebesar 2.95 karena Fhitung>Ftabel $(7,894>2.95)$ maka Ha diterima dan Ho ditolak artinya berpengaruh signifikan dari variabel pendapatan (X1), kesadaran (X2) dan kualitas layanan (X3) secara bersama-sama atau simultan terhadap kepatuhan wajib pajak (Y)

6. Nilai koefisien diterminasi Adjusted R Square R2=0,553. Nilai ini mempunyai arti bahwa variabel independen secara bersama-sama memberikan sumbangan sebesar 55,3\% dalam mempengaruhi variabel dependen dengan kriteria sedang.

Saran

1. Diharapkan perlu peningkatan penyuluhan pajak ke Desa-Desa terutama di Desa Datar Lebar II Agar bisa mengatur dan mengarahkan masyarakat akan pentingnya membayar pajak.

2. Diharapkan untuk tidak terpaku hanya menggunakan faktor-faktor dalam penelitian ini yaitu Pendapatan, Kesadaran, Kualitas Pelayanan.

\section{DAFTAR PUSTAKA}

Adesina Olugoke Oladipupo dan Uyioghosa Obazee. 2016. Tax Knowledge, Penalties, and Tax Complience in Small and Medium Scale Enterprise in Nigeria. Nigeria: University of Benin

Adesina Olugoke Oladipupo dan Uyioghosa Obazee. 2016. Tax Knowledge, Penalties, and Tax Complience in Small and Medium Scale Enterprise in Nigeria. Nigeria: University of Benin.

Agow, L. L., J. M. L. Umboh, dan H. Lestari. 2017. Faktor-Faktor yang Berhubungan dengan Pemberian ASI Eksklusif di Wilayah Kerja Puskesmas Motoboi Kecil Kotamobagu. Community Health 2(1): 30-40. 
Agung \& Adi Erawati. 2013. Pengaruh Pajak Daerah Dan Retribusi Daerah Terhadap Tingkat Pengangguran Dengan Belanja Modal Sebagai Variabel Pemoderasi. Fakultas Ekonomi dan Bisnis Universitas Udayana (Unud), Bali, Indonesia

Agustiningsi, Wulandari. 2016. Pengaruh Penerapan E-Filing, Tingkat Pemahaman Perpajakan dan Kesadaran Wajib Pajak terhadap Kepatuhan Wajib Pajak di KPP Pratama Yogyakarta. Jurnal Nominal/Vol.5 No.1

Anniza. 2017. Faktor-Faktor Yang Mempengaruhi Kepatuhan Wajib Pajak Di Kkp Pratama Pamekasan. Program Studi Akuntansi Fakultas Ekonomi dan Bisnis Universitas Wiraraja

Arikunto, Suharsimi. 2016. Prosedur Penelitian Suatu Pendekatan Praktik Edisi Revisi. Jakarta: Rineka Cipta.

Asriyani, Y., \& Susena, K. C. (2016). Faktor-faktor yang Mempengaruhi Kepatuhan Wajib Pajak Bumi dan Bangunan di Kecamatan Teluk Segara Kota Bengkulu. Ekombis Review, 4(2).

Beti Betriani, Karona Cahya Susena, \& Nurzam. (2021). The Effect Of Taxpayer Awareness On Regional Tax Receiving On Regional Financial Agency Kaur District.Jurnal Ekonomi, Manajemen, Bisnis Dan Akuntansi Review, 1(1), 18 -.

Boediono. 2013. Ekonomi Moneter Edisi 4. Yogyakarta: BPFE

Danarsi. 2016. Faktor-Faktor Yang Mempengaruhi Kepatuhan Wajib Pajak Dalam Membayar Pajak Mobil Dengan Diberlakukannya Pajak Progresif Di Kota Surakarta. Fakultas Ekonomi, Progam Studi Akuntansi Universitas Islam Batik Surakarta.

Departemen Pendidikan Nasional. 2014. Kamus Besar Bahasa Indonesia Cetakan ke delapan Belas Edisi IV. Jakarta: Gramedia Pustaka Utama

Direktorat Jenderal Pajak, Undang-undang Nomor 28 Tahun 2007 tentang Perubahan Ketiga atas Undang-undang Nomor 6 tahun 1983 tentang Ketentuan Umum dan tata Cara Perpajakan.

Ferdinand, Augusty. 2014. Metode Penelitian Manajemen. BP Universitas Diponegoro. Semarang.

Ferdinand, Augusty. 2014. Metode Penelitian Manajemen. BP Universitas Diponegoro. Semarang.

Ghozali, Imam. 2011. Aplikasi Analisis Multivariate Dengan Program SPSS. Semarang: Badan Penerbit Universitas Diponegoro.

Ghozali, Imam. 2011. Aplikasi Analisis Multivariate Dengan Program SPSS. Edisi Kedua. Semarang: Badan Penerbit Universitas Diponegoro.

Gilarso. 2014. Pengantar Ilmu Ekonomi Mikro. Yogyakarta : Kanisius, edisi 5.

Handayani \& Elva Nuraina. 2012. Pengaruh Pajak Daerah Dan Dana Alokasi Khusus Terhadap Alokasi Belanja Daerah Kabupaten Madiun. Pendidikan Akuntansi IKIP PGRI MADIUN

James, Simon dan Clinton Alley. 2014. Tax Compliance, Self-Assessment and Tax Administration. Journal of Finance and Management in Public Services, Vol. 2: 27- 42

Kamus Umum Bahasa Indonesia. 2014. Diakses melalui website. www.kamusbesarbahasaindonesia.com

Kusumawati dan Kumadji, S., 2016, "Analisis Faktor-Faktor Pembentuk Electronic Word-of-Mouth (eWOM) dan Pengaruhnya Terhadap Minat Beli (Survei pada Followers Akun Instagram @saboten_shokudo)", Jurnal Administrasi Bisnis (JAB), Vol. XXXVII 1, Agustus, hal. 148-15

Lestari. 2017. Pengaruh Kesadaran Wajib Pajak Dan Sanksi Pajak Terhadap Kepatuhan Wajib Pajak Orang Pribadi Pada Kantor Pelayanan Pajak Pratama Batam. Journal of Accounting \& Management Innovation, Vol.1 No.2, July 2017

Lumbantoruan, Amber. 2012. Analisis Perbedaan Perhitungan Laba Kena Pajak Menurut Laporan Keuangan Komersial dan Laporan Keuangan Fiskal. Jurnal Ilmiah Akuntansi, Vol. 1 (2): 21-30

Mardiasmo. 2016. Perpajakan Edisi Revisi Tahun 2016. Yogyakarta:Penerbit Andi.

Notosoedirjo Moeljono dan Latipun. 2012. Kesehatan Mental (Konsep Penerapannya). Malang: UMM Press.

Nurmantu, Safri. 2010. Pengantar Perpajakan. Jakarta: Kelompok Yayasan Obor Oladipupo dan Obazee. 2016. Perencanaan Perpajakan . Jakarta: PT Bumi Aksara Rachman, Rinda dan Gita. 2017. Faktor-Faktor Yang Mempengaruhi Keberhasilan Penerimaan Pajak Daerah. Bandung: PT Refika Aditama. 
Safri Nurmantu. 2010. Pengantar Perpajakan. Jakarta: Kelompok Yayasan Obor

Singarimbun, Masri dan Sofian Effendi. 2012. Metode Penelitian Survei. Jakarta: LP3ES

Situs pajak: https://www.pajak.go.id/

Soemitro. 2014. Asas dan Dasar Perpajakan 1 dan 2. Bandung: PT Refika Aditama.

Sugiyono. 2013. Metode Penelitian Kuantitatif, Kualitatif dan R\&D. Bandung: CV. Alfabeta

Sulistyiwati, Diah. 2011. Pengaruh Pajak Daerah, Retribusi Daerah, Dana Alokasi Umum, dan Dana Alokasi Khusus Terhadap Alokasi Belanja Modal. Fakultas Ekonomi Universitas Diponegoro Semarang

Undang-undang Nomor 28 Tahun 2007 Pasal 1 ayat 2

Undang-undang nomor 28 Tahun 2009 tentang Pajak Daerah dan Retribusi Daerah

UUD 1945 pasal 23 ayat 2

Winardi. 2015. Manajemen Prilaku Organisasi. Edisi Revisi, Prenada Media Group, Jakarta.

Wulandari. 2016. Pendekatan Penganggaran Daerah dan Akuntansi Keuangan Daerah. Badan Penerbit Universitas Diponegoro Semarang.

Zain, Mohammad. 2010. Himpunan Undang-Undang Perpajakan. PT. Indeks: Jakarta. 